\title{
1. Copyright in the expanded field: on land art and other new mediums
}

\section{Xiyin Tang*}

\section{INTRODUCTION}

It is about fifteen hundred feet in length and fifteen feet wide, built from 6,650 tons of basalt rocks and earth. ${ }^{1}$ It sits just south of Rozel Point, in Utah's Salt Lake, next to swirls of black oil from abandoned rigs. Thousands of people a year make the pilgrimage to see it as they are photographed from above, standing like tiny ants atop the salt as if minute stars dotting a constellation. For the rest of us, we see it only through photographs, and they are almost always aerial views, in which the swirl cuts across its site like a 'strange footprint on the shores of the unknown'. As it turns out, 'even the artist is startled to discover that this footprint is our own'. ${ }^{3}$

Is it architecture? Is it a larger-than-life sculpture? Is it nature? Is it a man-made imitation of the former? Is it site? Is it life itself?

It is Robert Smithson's Spiral Jetty, an iconic earthwork or piece of 'land art' that has, since its creation, been the stuff of art historical myth and fable - not least of which was its submersion under water at the same time that Smithson died in a fatal plane crash, creating a sort of double

* This chapter takes its name from the 1978 essay by Rosalind Krauss titled 'Sculpture in the Expanded Field', which perfectly documents the phenomenon of post-1960s artists working in an expanded medium that encompasses elements of architecture, landscape, nature, and traditional sculpture. See, Rosalind Krauss, Sculpture in the Expanded Field, 8 October, 30-44 (1979). An earlier version of this essay was originally printed in the Hofstra Law Review. Reprinted with permission.

1 Lynne Cooke, A Position of Elsewhere. In Robert Smithson: Spiral Jetty (Lynne Cooke et al. eds., University of California Press, 2005) 53, 53.

2 Ann Reynolds, At the Jetty. In Robert Smithson: Spiral Jetty, supra note 1, at 73,73 .

3 Ibid. 
negative or disappearance. ${ }^{4}$ While the jetty is perhaps the most famous earthwork, it is not alone. Walter de Maria's Lightning Field in New Mexico, Michael Heizer's Effigy Tumuli in Illinois, and James Turrell's Roden Crater in Arizona are just a few of the many examples of artists working in expanded mediums that implicate site, architecture, sculpture, and nature-as-material.

US copyright law, on the other hand, only extends protection to eight categories of works: literary works, musical works, dramatic works, choreographic works, pictorial/graphic/sculptural works, motion pictures, sound recordings, and architectural works. ${ }^{5}$ Numerous legal scholars have already noted that evolving forms of art - not just appropriation art (for which fair use remains a field ripe with possibilities and problems) ${ }^{6}$ but conceptual art, performance art, and temporal 'happenings', which are notable for their ephemerality ${ }^{7}$ - seem incompatible and fundamentally unprotectable under the very laws intended for their protection. Land art, specifically, does not neatly fit into any of the above-named categories. However, few solutions outside of legislative reform have been posed. ${ }^{8}$

Yet the fast-changing nature of art likely renders legislative reform impractical, and would leave new legislation largely obsolete in its wake. What is needed, then, are creative solutions within already-existing law - solutions that may lie outside of the copyright statute itself. Artists asserting copyright claims already frequently assert trademark and right

4 Ibid.

17 U.S.C. $\S 102(2006)$.

See, e.g. Alex Kozinski and Christopher Newman, What's So Fair About Fair Use?, 46 J. Copyright Soc'y U.S. 513 (1999); Gideon Parchomovsky and Phillip J. Weiser, Beyond Fair Use, 96 Cornell L. Rev. 91, 100-1 (2010); Xiyin Tang, That Old Thing, Copyright . . .. Reconciling the Postmodern Paradox in the New Digital Age, 39 AIPLA Q.J. 71, 86-94 (2011).

7 See, e.g., Randall Bezanson and Andrew Finkelman, Trespassory Art, 43 U. Mich. J. L. Reform 245 (2010); Charles Cronin, Dead on the Vine: Living and Conceptual Art and VARA, 12 Vand. J. Ent. \& Tech. L. 209 (2010).

8 See, Virginia M. Cascio, Hardly a Walk in the Park: Courts' Hostile Treatment of Site-Specific Works Under VARA, 20 DePaul J. Art, Tech. \& Intell. Prop. L. 167 (2009); Bryan J. Hopping, A Proposal for the WTO to Enhance Moral Rights Protection, 11 Gonz. J. Int'1 L. 2 (2007-2008); Lauren Ruth Spotts, Phillips Has Left VARA Little Protection for Site-Specific Artists, 16 J. Intell. Prop. L. 297 (2009). However, Randall Bezanson and Andrew Finkelman have applied real property principles to 'trespassory' art (i.e. art that involves trespassing in spaces) - including endowing artists with a limited 'easement' to use private property for artistic purposes. See Bezanson and Finkelman, supra note 7 at 277-9. 
of personality claims as well, suggesting an awareness that personhood, branding, and artistic creation are all interlinked. ${ }^{9}$ But as evolving forms of art begin to look less comfortably like traditional artworks, perhaps it would serve us well to also expand our thinking beyond intellectual property law. This is where focusing on the specific problem of land art or earthworks can prove instructive in demonstrating that copyright need not be the only answer to the exasperating problem of a copyright doctrine hostile to contemporary art.

Art historian Rosalind Krauss has traced art history's suspicions of the new hybridity of sculpture to 'the modernist demand for the purity and separateness of the various mediums'. ${ }^{10}$ While land art may seem 'rigorously logical' from 'within the practice of postmodernism', where 'practice is not defined in relation to a given medium - sculpture - but rather in relation to the logical operations on a set of cultural terms, for which any medium - photography, books, lines on walls, mirrors, or sculpture itself might be used', ${ }^{11}$ contemporary copyright law still remains very much focused and, might I add, dependent on, very specific notions of modernist medium purity, autonomy, and specificity. Indeed, throughout the history of copyright law, judges have engaged in exactly the kind of modernist definitional line-drawing that attempts to reduce, via a single set of finite, discrete criteria, a specific medium to its 'inherent' end logic. ${ }^{12}$ Thus if legal scholarship from the past decade has insisted on copyright's outdated reliance on the notion of the 19th-century romantic author, ${ }^{13} \mathrm{I}$ argue instead that it is precisely the 20th-century avant-garde that copyright law owes its debt to in its insistence on the purity of the medium itself.

Further, land art proves a timely and especially interesting case study for our purposes, as two circuit court decisions have essentially deemed this hybrid art form unprotectable - either under copyright law or its

9 See, e.g., Stacey L. Dogan and Mark A. Lemley, What the Right of Publicity Can Learn from Trademark Law, 58 Stan. L. Rev. 1161 (2006); Xiyin Tang, The Artist as Brand: Toward a Trademark Conception of Moral Rights, 122 Yale L.J. 218 (2012).

${ }_{10}$ Rosalind Krauss, Sculpture in the Expanded Field. In The Originality of the Avant-Garde and Other Modernist Myths (MIT Press, 1985) 277, 288.

11 Ibid.

12 See infra, notes 21-23 and accompanying text.

13 See, e.g., Peter Jaszi, Toward a Theory of Copyright: The Metamorphoses of 'Authorship', Duke L.J. 455 (1991); Martha Woodmansee, The Genius and the Copyright: Economic and Legal Conditions of the Emergence of the 'Author', 17 Eighteenth-Century Stud. 425, 428-30 (1983-1984) (both arguing that authorship is a socially-constructed category reliant on the Romantic notion of an inspired genius). 
newer moral rights component, the Visual Artists Rights Act of 1990 (VARA).${ }^{14}$ I focus the first part of this chapter on these two decisions and their implications for earthworks. The second part then links this legal reasoning to a surprising predecessor: the 20th-century avant-garde insistence on medium purity, not the 19th-century Romantic author construct that most legal scholars have focused on in their analysis of copyright doctrine's limitations. Applying this reasoning, I come, in my last part, to the seemingly disappointing conclusion that this new form of hybrid art is, logically, uncopyrightable. Yet, I propose two new forms of protection under real property and tort law - specifically, the claims of trespass and nuisance - which seem to most aptly reflect land art's site-specific aspirations. Above all, I suggest that we may think of legal protection for artworks not as an either-or (either it is uncopyrightable and hence unprotectable or vice versa), but as existing in an expanded field that encompasses other viable options for redress like real property or tort law.

\section{THE LEGAL DILEMMA OF NON-TRADITIONAL ART FORMS}

This section begins by reviewing a few of the fundamental principles of copyright law that this chapter is concerned with, before examining how recent court decisions have applied these requirements to works of art that move beyond the walled-in ethos of the museum.

\subsection{Copyright Basics}

There are a few strange requirements of copyright law that will form the chief concerns of this chapter and its case law analysis. I will review them each briefly in this section, but they can be summed up into three major themes: fixation, idea/expression dichotomy, and medium categorization.

The first two are relatively straightforward. One of the most basic requirements for copyright protection is that an 'original work ... of authorship [be] fixed in a tangible medium'. ${ }^{15}$ The fixation-in-atangible-medium requirement interacts with and informs the other major requirement of copyright law: that only expression, not ideas, can be

14 The two cases are Kelley v. Chicago Park Dist., 635 F.3d 290 (7th Cir. 2011) and Phillips v. Pembroke Real Estate, Inc., 459 F.3d 128, 131 (1st Cir. 2006).

1517 U.S.C. $\S 102(2006)$. 
copyrighted. ${ }^{16}$ After all, if an idea is abstract, expression is concrete, manifesting itself in something physical and tangible. Indeed, the two requirements are frequently discussed together by courts in examining whether a work satisfies this most basic of requirements. ${ }^{17}$ But, of course, the two present their own, unique problems. Even presuming that an 'idea' were 'expressed' in a concrete way (in a performance, for example), if there is no tangible record of it (in a recording, for example), that expression would not be copyrightable, either. ${ }^{18}$

The third major concern of this chapter is a surprising one, for the very word 'medium' seems to be more of an art historical preoccupation than a legal one. For modernism, which reached its apex in the 1960s with the dominance of such art critics as Clement Greenberg, medium specificity was an imperative that drove critics to attempt to distill just what made a painting a painting, a sculpture a sculpture, a photograph a photograph, and art art. Greenberg, the king of modernist art critics, penned his most famous work on medium specificity - 'Modernist Painting', in which he defines what painting is - a purely visual experience that is first and foremost flat, rendered so by the flatness of its pictorial surface. ${ }^{19}$

Yet copyright, too, relies on assumptions about the inherent characteristics of a specific medium, even if such assumptions are implicit rather than made explicit. For example, in deciding that an object which has utilitarian concerns simply cannot qualify for copyright protection, ${ }^{20}$ courts are doing more than adhering to the letter of the law, which states that useful articles belong to the realm of patents ${ }^{21}$ - they are saying, rather, that

16 Ibid. ('In no case does copyright protection for an original work of authorship extend to any idea, procedure, process, system ... concept, principle, or discovery, regardless of the form in which it is described, explained, illustrated, or embodied in such work').

17 See, Dollcraft Industries, Ltd. v. Well-Made Toy Mfg. Co., 479 F.Supp. 1105, 1113 (E.D.N.Y. 1978) ('[C]opyright law protects an individual's concrete expression of his own idea').

18 See, e.g., Hoopla Sports and Entertainment, Inc. v. Nike, Inc., 947 F.Supp. 347,354 (1996) (noting that even if a basketball game is copyrightable, the fact that it was not recorded renders it ineligible for copyright).

19 Clement Greenberg, Modernist Painting. In The Collected Essays and Criticism: Modernism with a Vengeance, 1957-1969, Vol 4 (1960) (University of Chicago Press, 1995) at 85.

20 Consider the famous case of Brandir Int'l, Inc. v. Cascade Pac. Lumber Co., 834 F.2d 1142 (2d Cir. 1987), in which the court had to decide whether a bike rack was sufficiently artistic to be considered sculpture or else influenced by utilitarian concerns and thus a product of industrial design.

21 17 U.S.C. $\S 101(2006)$. 
artworks, like Greenberg's flat picture plane, should be inherently useless, and the more useless it is, the more likely it is to be eligible for copyright. Then again, some might object that this leaves us merely with a distinction between copyrightable artworks and non-copyrightable non-art, without necessarily defining mediums within the copyright statute.

Yet land art, in traversing the boundaries of sculpture, architecture, land, or site, brashly confronts judges with the problem of medium definition within the copyright statute itself. Even more importantly, consider the Visual Artists Rights Act of 1990 (VARA), which gives the author of a painting, drawing, print, sculpture, or photograph, existing in a copy of 200 or less, the right to prevent the destruction, distortion, mutilation, or other modification of a work that would be prejudicial to the author's reputation. ${ }^{22}$ A work labelled 'architecture' instead of 'sculpture', then, would not be eligible for VARA protection. Judges could either decide, for example, that land art is more like 'architecture' and hence not subject to VARA, or else that it is not art at all.

As we will see below, the few courts that have confronted the issue of land art have also implicitly confronted the issue of medium specificity what a medium is, what it should be, what it contains, what it does. But their failure to acknowledge the very assumptions they are making about medium has led to much confusion and, as others have pointed out, poor case law. ${ }^{23}$ For as it turns out, the two courts that have most notoriously opined on land art have done so from a highly modernist-inflected view of sculpture: that it should be man-made, static and unchanging, and, above all, that it is a self-contained monument that should sit on a pedestal within the white walls of the museum.

\subsection{Phillips v. Pembroke: Stripping Land Art of VARA Protection}

Yet earthworks do not fit comfortably into the self-contained, walled-in ethos of the museum and its pedestals. Minimalism, with its emphasis on atmosphere and environment, was the natural predecessor of these large-scale site-specific works that cannot be easily divorced from their surroundings. In a problematic case for this new hybrid sculpture, the court created a judicially-imposed VARA carve-out for site-specific art, holding that VARA's 'integrity' right (the right to prevent modifications

2217 U.S.C. $\$ 106(A)$ (2006).

23 See, e.g., Rachel E. Nordby, Off of the Pedestal and Into the Fire: How Phillips Chips Away at the Rights of Site-Specific Artists, 35 Fla. St. U. L. Rev. 167, 186 (2007); Cascio, supra note 8, at 184-5. 
and mutilations of the art work) did not apply to removals of site-specific art from its, well, site. In Phillips v. Pembroke Real Estate, the work in question was one by an artist named David Phillips, who designed a series of stoneworks for Boston's Eastport Park. These sculptures, which depicted Zodiac signs and marine animals, contained granite stones that mirrored those stones located along the Boston Harbor. ${ }^{24}$ In 2003, the defendant, Pembroke Real Estate, moved to relocate some of Phillips' sculptures off of the park grounds. Phillips sued under VARA, claiming the integrity right and arguing that the park itself, including the granite paths and the sea walls of Boston Harbor near which it was located, was integral to his work. The First Circuit disagreed - to say the least. Rather than simply holding that the sculpture could be dissembled and removed without violating VARA rights so long as the integrity of the sculptures themselves were kept intact, the court went further in holding that no work of site-specific art is protected under VARA.

Their reasoning relied on the 'public presentation' exception of VARA, which states that 'the modification of a work of visual art which is the result of conservation, or of the public presentation, including lighting and placement, of the work is not a destruction, distortion, mutilation, or other modification'. ${ }^{25}$ The court below had interpreted this to mean that VARA allows for the removal of the work from its site but requires that the work itself be kept intact. ${ }^{26}$ There is evidence that this was in line with Congress's wishes when drafting VARA, as they noted that 'the removal of a work from a specific location comes within the [presentation] exclusion because the location is a matter of presentation' ${ }^{27}$

But the First Circuit went farther. It first acknowledged Phillips' argument that the site itself is integral to site-specific art, helped along by a few testimonies from those within the art historical community. One testimony, for example, opined to the court that ' $[\mathrm{m}] \mathrm{uch}$ of modern sculpture does not exist separate from its context, but rather integrates its context with the work to form, ideally, a seamless whole'. ${ }^{28}$ The First Circuit, applying this logic, deemed it an illogical reading of VARA that the act would both protect site-specific art against modification or mutilation and yet allow for precisely its modification or mutilation by divorcing it from its site, which operates as part of the work. ${ }^{29}$

\footnotetext{
24 Phillips v. Pembroke Real Estate, Inc., 459 F.3d 128, 131 (1st Cir. 2006).

2517 U.S.C. $\S 106(\mathrm{~A})(\mathrm{c})(2)(2006)$.

26 See, Phillips, 459 F.3d at 140.

27 H.R. Rep. No. 101-514, at 12 (1990).

28 Phillips, 459 F.3d at 134.

29 Ibid. at 140.
} 
Needless to say, the reasoning is slightly attenuated, though best elucidated in this one either-or: '[e]ither VARA recognizes site-specific art and protects it, or it does not recognize site-specific art at all'. ${ }^{30}$ The court's ultimate decision on the latter reflects a deep antagonism to land art's uncomfortable position between that of traditional art objects, governed by the law of chattels (i.e. movable property), and land, governed by the law of real property.

American law is already deeply protective of the rights that attach with any piece of property, including chattel - VARA has been roundly criticized for its limitations on what an owner may do with his own painting, including destroy it, alter it, and paint over it. ${ }^{31}$ The First Circuit's refusal to grant VARA protection to land art, then, shows judges' reluctance to extend VARA any farther than the traditional categories of 'painting, prints, sculpture, and drawing' that it protects. (Further, both the Phillips and Kelley court, discussed below, have interpreted these categories as autonomous, separate mediums, rather than loose categories within which hybrids may be constructed.) Real property - land - on the other hand, presents graver concerns, as the court suggests that 'owners of nearby property who had nothing to do with the purchase or installation of Phillips' works would be subject to claims that what they do with their property has somehow affected the site and has, as a result, altered or destroyed Phillips' works' ${ }^{32}$

What Phillips leaves open, then, is whether site-specific art or land art is copyrightable at all. One possible reading of Phillips suggests that the court's concern solely with modification or destruction - and ownership, in general - could nonetheless qualify land art as an architectural work, for which 'the owners of a building embodying an architectural work may, without the consent of the author or copyright owner of the architectural work, make or authorize the making of alterations to such building, and destroy or authorize the destruction of such building' ${ }^{33}$ This exception nicely satisfies the First Circuit's concern with property ownership, as the statute's divorce of building from copyrightable work (in which a building owned by another may contain a copyrightable architectural work owned by the artist) would transfer over nicely to the land art context. Thus we could analogize the copyrighted architectural work to the artwork itself, and the building to the site that surrounds it.

Phillips, then, was at least hinting towards one viable option for placing

\footnotetext{
30 Ibid.

31 See, Amy Adler, Against Moral Rights, 97 Cal. L. Rev. 263 (2009).

32 Phillips, 459 F.3d at 142.

33 17 U.S.C. $§ 120$ (2006).
} 
land art more firmly within the architectural medium - for legal purposes, at least. But in a more recent case involving land art, the court firmly moved in an even more radical direction - of declaring the uncopyrightability of land art.

\subsection{Kelley v. Chicago Park District: Stripping Land Art of all Copyright Protection}

If Phillips presented a question of medium categorization, in which defining land art as architecture (or at least as not-sculpture) may entail losing certain rights that sculptures are subject to, Kelley eschews the issue for the very basics of copyrightability instead - the idea/expression dichotomy and the fixation-in-a-tangible-medium requirement. The case centred around a wildflower garden created by the artist Chapman Kelley. 'Wildflower Works' consisted of 'two enormous elliptical flower beds, each nearly as big as a football field, featuring a variety of native wildflowers and edged with borders of gravel and steel'. ${ }^{34}$ 'Wildflower Works' immediately calls to mind other 'expanded field' artworks like Maya Lin's Wave Field at Storm King, a wavy expanse of lush green grass framed by the forest beyond. ${ }^{35}$

Chapman had planted his work in 1984 in the Chicago Park District, but the condition of the flower beds began deteriorating by the early 2000s. By then, the city decided to modify the garden, 'substantially reducing its size, reconfiguring the oval flower beds into rectangles, and changing some of the planting material' ${ }^{36}$ Chapman sued under VARA, claiming that the city had engaged in an unauthorized modification and mutilation of his work.

The Seventh Circuit began by immediately calling into question whether 'Wildflower Works' can be thought of as a painting or a sculpture at all - a question of medium. 'To qualify for moral-rights protection under VARA, Wildflower Works cannot just be "pictorial" or "sculptural" in some aspect or effect, it must actually be a "painting" or "sculpture". Not metaphorically or by analogy, but really', the court writes. ${ }^{37}$ Unfortunately, the court never articulates just what about a work makes it 'really' a painting or sculpture, rather than having mere 'sculptural' or

$34 \quad 635$ F.3d at 291.

35 See, Holland Cotter, Where the Ocean Meets the Mountains, N.Y. Times (7 May 2009), http://www.nytimes.com/2009/05/08/arts/design/08lin.html?pagewante $\mathrm{d}=$ all.

$36 \quad 635$ F.3d at 291.

37 Ibid. at 300 . 
'pictorial' qualities. Perhaps in order to avoid the more vexing issue of determining just what each medium is, the court moves on to a more basic (and seemingly simpler) question: whether the work can be copyrighted at all, as 'a living garden lacks the kind of authorship and stable fixation normally required to support copyright'.$^{38}$ The first, the court maintains, is true because much of 'Wildflower Works' owes its form to nature - 'the colors, shapes, textures, and scents of the plants originates in nature, not in the mind of the gardener [the derivative term they have now bestowed upon Chapman]'. ${ }^{39}$ The second, that the work is not fixed, is also true, the court opines, because '[a] garden's constituent elements are alive and inherently changeable, not fixed' ${ }^{40}$ Because the work is unable to cross even the most basic of all copyright hurdles - originality and fixation Chapman does not own a copyright, let alone moral rights, in the work.

Yet this reasoning is somewhat attenuated, suggesting the deep discomfort with medium that led the court to address a more straightforward question about fixation instead. However, the idea that a living garden lacks fixation would also call into question much of sculpture made from materials meant to degrade or wear over time - even man-made ones like steel. The sculptures of Richard Serra, for example, are not constant, stable, unchanging - but are intended to register the marks and wear of life as the steel ages, changing in color and texture throughout the years. ${ }^{41}$ In this sense, even more 'traditional' sculpture is not 'fixed' under the court's definition. And ruling out flowers as merely an 'idea' of nature seems silly to say the least - plenty of sculptures depend on natural materials (sand, for example, in the sculptures of Joseph Beuys) for their existence. ${ }^{42}$

All of which suggests that what we are really getting at in both these opinions are basic assumptions about what sculpture - and really, art - is. As I argue in the following part, judges' natural distrust of land art owes much to modernism's insistence on a purity of art form - meant to be

38 Ibid. at 304.

39 Ibid.

40 Ibid.

41 Deborah Solomon, Our Most Notorious Sculptor, N.Y. Times (8 October 1989), http://www.nytimes.com/1989/10/08/magazine/our-most-notorious-sculpto r.html?pagewanted $=10 \& \mathrm{src}=\mathrm{pm}$ ('Cor-Ten steel [the material Serra makes his sculptures from] was designed to acquire a dark, even patina of rust over time, and this natural process endows Serra's sculptures with a handsome brown hue. The rust can function metaphorically, too, reminding the viewer of his own inevitable decay').

${ }_{42}$ Mary and Leigh Block Museum of Art, Joseph Beuys: Sand Drawings, Block Museum of Art, http://www.blockmuseum.northwestern.edu/view/exhibitions/ past-exhibits/2012/joseph-beuys-sand-drawings.html. 
placed in the museum, free from the every day, and transcendent in its aspirations.

\section{COPYRIGHT IN THE EXPANDED FIELD: WHAT COPYRIGHT LAW OWES TO MODERNIST MEDIUMS' SPECIFICITY}

I have already suggested that copyright law, like modernism, focuses on distilling a medium down to its inherent end logic. ${ }^{43}$ Yet both Phillips and Kelley seem less guided by what sculpture or painting is than by an almost intuitive, implicit idea of what it isn't. And yet what are both judges so convinced that art shouldn't be? For this, we turn to another great modernist critic, Michael Fried, who famously set out to define what sets 'art' apart from mere 'objects' in his 1967 essay 'Art and Objecthood'. For if this chapter had begun by positing that perhaps it is not just the 19th-century notion of the romantic author-genius that copyright law owes its debt to, but its 20th-century avant-garde successors, a re-reading of Fried's article garners unexpected parallels between the rhetoric of the Kelley court and the high modernist mantra.

Fried, in his polemic against minimalist art, termed the works of well-known artists like Donald Judd, Carl Andre, and Robert Morris as objects, not artworks. Inspired by Greenberg's earlier rant against minimalism, in which he argued that ' $[\mathrm{m}]$ inimal works are readable as art, as almost anything is today_including a door, a table, or a blank sheet of paper', ${ }^{44}$ Fried takes this new 'condition of non-art' and calls it 'objecthood'. It is as though objecthood alone can, in the present circumstances, secure something's identity, if not as non-art, at least as neither painting nor sculpture; or as though a work of art - more accurately, a work of modernist painting or sculpture - were in some essential respect not an object' ${ }^{45}$ Here, we see Fried and Greenberg visibly working to categorize the new sculpture as something other than - other than painting, other than sculpture, maybe non-art, at best an object - just as the Kelley court expressed suspicion at granting VARA protection to something that did not fit neatly into the traditional category of painting qua painting or

\footnotetext{
43 Supra, notes 20-23 and accompanying text.

44 Clement Greenberg, Recentness of Sculpture. In The Collected Essays and Criticism: Modernism with a Vengeance, 1957-1969 (University of Chicago Press, 1995) at 250, 253-4.

${ }_{45}$ Michael Fried, Art and Objecthood. In Art and Objecthood: Essays and Reviews (University of Chicago Press, 1998) 148, 152.
} 
sculpture qua sculpture. The court's categorization of 'Wildflower Works' as merely having 'sculptural' or 'painterly' qualities turns what Rosalind Krauss had termed the expanded sculpture's negation-as-positive into a negation-as-negative (surely how Greenberg and Fried would see it): 'not-sculpture' or 'not-painting' does not merely expand into a quaternary field of 'not-sculpture as painting or not-painting as sculpture' ${ }^{46}$ Rather, 'not-sculpture' or 'not-painting' becomes, simply, not-art.

Yet why is this so? Why is Fried so eager to categorize minimalism as not-art, as condemned to 'objecthood' status? Similarly, how does the Kelley court come to the conclusion that 'Wildflower Works', too, is not art, but at best a garden, an ordinary work of landscaping in the middle of a public park? Surprisingly, we can view the justifications both provide as one and the same. That is, we can read the Seventh Circuit's anxiety over the 'not fixed', intangible nature of 'Wildflower Works' as parallel to Fried's distrust of the 'endlessness' of minimalist sculpture.

'Endlessness', Fried writes, or the condition of 'being able to go on and on, even having to go on and on, is central both to the concept of interest and to that of objecthood' ${ }^{47}$ And so in many ways, experience blurs art and life, just as minimalist objects are not self-contained, but rely on the viewer, on the room, on atmosphere and the sounds and air of light itself for its effect. Certainly, Smithson's 'Spiral Jetty' takes the idea of art as experience or art-blurred-into-life to its next logical progression, as viewers travel along the length of the jetty one step at a time in the long journey towards its centre. In person, the jetty is not viewable in an instant, not graspable as a whole. And no two individuals' experience of the work will be the same - the jetty, whether submerged, re-emerged, laced with rain or dry from drought, is inextricably linked with atmosphere, with the time of day or the workings of the weather. As such, it, like the works of its minimalist predecessors that Fried railed against, lacking the 'presentness ... that one experiences as a kind of instantaneousness, as though if only one were infinitely more acute, a single infinitely brief instant would be long enough to see everything, to experience the work in all its depth and fullness, to be forever convinced by it'. ${ }^{48}$

It is this instantaneousness that modernist art aspires towards (as in the works of Kenneth Noland or Jules Olitski or David Smith or Anthony Caro, in which 'at every moment the work itself is wholly manifest',

46 Rosalind Krauss, Sculpture in the Expanded Field. In The Originality of the Avant-Garde and Other Modernist Myths 277, 283 (MIT Press, 1985).

47 Ibid. at 166.

48 Ibid. at 167. 
contends Fried), ${ }^{49}$ and this instantaneousness that minimalist objects lack. For the latter, 'the experience in question persists in time, and the presentment of endlessness . . . is essentially a presentment of endless or indefinite duration' ${ }^{50}$ So we return to the Kelley court's emphasis on 'fixation in a tangible medium', which now manifests itself as an understanding of art as precisely Fried's modernist notion of instantaneousness. A work of art, in other words, should not persist in time, but should be fixed in one moment, a brief instant that captures the work in all its depth and fullness, in its oneness and wholeness, forever. A work of art cannot go on and on, ever-changing, inherently alive as the flowers in Chapman's work. It is this suspicion of the intangibility of experience itself that the Kelley court seems to abhor, the idea that art may expand beyond the object itself to encompass the conditions of life and time. Somewhere we may read the mystic's hope for immortality in here, for transcendence. Art should endure even as we must die. Hence why Fried disdains minimalist art, calling it 'literalist' instead, in what could be a direct evocation of the drabness of life that art should aim to transcend. ${ }^{51}$ 'We are all literalists most or all of our lives', Fried writes. But 'presentness is grace'. ${ }^{2}$

\section{A CREATIVE SOLUTION FOR SITE-SPECIFIC ART: LOOKING OUTSIDE INTELLECTUAL PROPERTY LAW}

The phrase 'beyond IP' has, in recent years, come into fashion. The premise that other forms of law, regulation, or social norms could govern, stimulate, encourage, or incentivize knowledge and information production is nothing new. ${ }^{53}$ However, few have considered the 'beyond IP' approach as applied to evolving forms of art - often times, the argument

49 Ibid.

50 Ibid. at 166.

51 Ibid. at 166.

52 Ibid. at 168 .

53 The literature I consider 'beyond IP' takes many forms. It could, for example, consider government regulation or incentives (i.e., prizes), open source data and other forms of public domain (i.e., 'non-IP' means of governing knowledge production). To name just a few examples, see Amy Kapczynski, The Cost of Price: Why and How to Get Beyond Intellectual Property Internalism, 59 UCLA L. Rev. 970 (2012); Jessica Litman, The Public Domain, 39 Emory L.J. 965 (2003); Yochai Benkler, Freedom in the Commons: Towards a Political Economy of Information, 52 Duke L.J. 1245 (2003). 
is centred on, instead, adapting IP law to accommodate art. ${ }^{54}$ In this section, I consider alternatives to land art protection that do not hinge on the medium-specific requirements of copyright law. These approaches, I argue, are more fitting for the expanded field of certain forms of art production, as they are also superior in that they do not seek either common law or statutory schemes that inevitably evolve more slowly than the art forms they would address. Rather, real property and tort law principles work for land art.

\subsection{But First, Why Shouldn't Land Art Be Considered 'Architecture' for Copyright Purposes?}

The decisions in Phillips and Kelley, while they have been roundly criticized by the art law community, seem to reach the most logical conclusion regarding the vexed relationship between the new expanded sculpture and moral rights. After all, work that invites modification or alteration from viewers themselves - in the form of footprints on the 'Spiral Jetty', for example, or a plucked flower from Chapman's 'Wildflower Works' cannot then claim the right to be free from modification or alteration. Similarly, land art's communitarian function suggests at least some need for a balancing of rights between public interest and artistic control - both Phillips and Kelley, after all, involved highly public works in city parks. Like architecture, which serves a public function as a monument or tourist attraction, it would seem at least reasonable that the public remain free to photograph large works of copyrighted land art. All of which might lead one to suggest - why not just definitively categorize land art as architecture? We would hence solve both the moral rights problem (as architectural works are not protected under VARA) and allow for public engagement with these highly visible works in the form of a pictorial representation exception. ${ }^{55}$ Moreover, land artists have themselves already acknowledged the architectural influences in their work, so the analogue seems a natural one. ${ }^{56}$

And yet some would argue that the right to control how, for example, the 'Spiral Jetty' appears in photographs and films is as important or more

54 See, e.g., Amy Adler, Fair Use and the Future of Art, 91 N.Y.U. L. Rev. 559 (2016); Megan Carpenter and Steven Hetcher, Function over Form: Bringing the Fixation Requirement into the Modern Era, 82 Fordham L. Rev. 2221 (2014).

5517 U.S.C. $\$ 120$ (2006).

56 See Krauss, supra note 10, at 287 (detailing artists' explorations of architecture, drawing, and site to form a hybrid she terms 'marked sites', which includes art others have termed site-specific art). 
important than the jetty itself - after all, most of us only know the jetty as a 'neatly framed ... striking still photographic image that is endlessly reproduced as the preferred symbol, elegant and concise, for "earth art", 57 Yet the question in this instance necessarily becomes a case-by-case one: a widely circulated, unauthorized image of the jetty might forever tarnish its reputation, but a relatively unknown photograph published by a tourist on his blog might not affect the jetty's public image at all.

This is where I suggest that artists working with the new sculpture in the expanded field similarly expand their legal remedies beyond that of copyright law to land art's natural analogue: real property law and the doctrines of trespass and nuisance. The former goes straight to the heart of ownership rights, and the latter to rights of the public.

\subsection{Trespass as One Form of Creative Control}

The doctrine of trespass is probably the more straightforward of the two. It acknowledges that owners have a 'bundle' of rights to their property, including the right to exclude others from entering and the right to place limitations on what one may do upon entering. Using a mix of property and contract law, then, owners of land art (or really, the owner of the site on which the land art sits - oftentimes they are aligned, as the Dia Art Foundation and Walter de Maria are in the example below) may appropriately place conditions on those entering - requiring, for example, any photography to be solely for personal use, or banning photography all together. Such is precisely the method that Dia uses with Walter de Maria's 'Lightning Field', which does not permit visitors to simply drop in, look around, and snap photos. Rather, access to and from the 'Lightning Field' is tightly controlled by Dia, which ferries visitors to the site only upon a twonight stay. ${ }^{58}$ Further, they are explicit about retaining the right to control the way 'Lightning Field' appears in photos. ${ }^{59}$ This makes sense for works like de Maria's, as the poles of Lightning Field undoubtedly look best when struck with lightning and lit up against a dark night sky. Dia, therefore, does not need a copyright claim to ban any unauthorized photos of 'Lightning Field' - they can simply assert a breach of contract action, as every visitor to the site has explicitly agreed not to publish, or take, any such photos.

However, Dia's approach to 'Lightning Field' does not transfer over as well to, for instance, the 'Spiral Jetty' context, as the sheer mass of it

57 Reynolds, supra note 2, at 73.

58 Geoff Dyer, Poles Apart, The New Yorker (18 April 2011) at 62, 65.

59 Ibid. 
makes the object visible from the air. Thus, even if Dia could easily limit what visitors do on the ground, they cannot contract with those chance passersby who spot the jetty from above and snap a few photos of it. The same applies to other mass-scale earthworks visible (and really, only viewable as whole) from above, like Michael Heizer's 'Effigy Tumuli', a massive compilation of earth mounds made to resemble creatures when viewed from the air. ${ }^{60}$

Furthermore, as noted above, trespass works only when the interests of the artist and the land owner are perfectly aligned. It should be every land artist's hope that if he does not himself own the land, then at least whoever does will act in the best interest of the work, neither destroying it nor altering it for the worse, and working to ensure that any unauthorized, unfavorable reproduction in film or photographs is halted. In a world in which we expect property owners to behave like rational actors, working diligently to increase property value and preserve what is valuable, this should not be an unrealistic expectation. Yet the current legal troubles of the jetty, in which the Dia Art Foundation (entrusted with the care of the jetty after Smithson passed) failed to renew its lease and has now (at least temporarily) lost control of the site to the State of Utah, leaves room to be pessimistic about the future of land art. ${ }^{61}$

In the absence of legal ownership of the land on which the art sits, artists hoping to preserve a certain degree of control over their works must look past the simpler gate-keeping methods of trespass and contract law. My proposal, then, turns to an unlikely source: tort law and applying the principles of nuisance to the unauthorized aerial photography/film context. $^{62}$

${ }^{60}$ Michael Heizer, Effigy Tumuli, Double Negative, http://doublenegative.tar asen.net/effigy_tumuli.html (last visited 21 September 2012).

${ }_{61}$ Glen Warhol, Control of Iconic Sculpture Spiral Jetty in Dispute, The Salt Lake Tribune, 23 June 2011, http://www.sltrib.com/sltrib/news/51970092-78/dia-jett y-lease-spiral.html.csp.

62 This chapter focuses on the reproduction and distribution rights of copyright (17 U.S.C. Section 106(1) and 17 U.S.C. Section 106(3) (2006)) because these are the two rights land artists will be most concerned with. Consider the other exclusive rights a land artist could assert if he held a copyright: the right to prepare derivative works and the right to display his work. However, land art's invitation to the public to interact with it renders a prohibition on derivative works impractical and likely directly inapposite to the artist's intentions, while its immovable state means that it can only be displayed in the one place it was built - the intended site. 


\subsection{Nuisance Law: Balancing Public Interest with Private Right}

Nuisance as a real property injury is a relatively new development in Anglo-American law, dating to the beginning of the 20th century.$^{63}$ Unlike trespass, which is a hard-and-fast rule with bright-line applicability (any unauthorized trespass upon a land is de facto wrongful), ${ }^{64}$ nuisance is a balancing test conducted by judges that weighs the competing interests of both parties. ${ }^{65}$ And unlike trespass, no physical intrusion is necessary - intangible intrusions, like dust particles, light, air, and noise - can constitute an actionable invasion. ${ }^{66}$ Courts have defined a nuisance as 'anything which interferes with the rights of a citizen, either in person, property, the enjoyment of his property, or his comfort ... A condition is a nuisance when it clearly appears that enjoyment of property is materially lessened' ${ }^{67}$ Courts will balance the landowner's interest in the enjoyment of his property with the social value of the activity alleged to cause the harm. ${ }^{68}$

Activities like air pollution emitting from a nearby factory and onto homeowners' land or noxious gas issuing from a smelting plant that substantially damaged plaintiffs' hedges and shrubs have been enjoined. ${ }^{69}$ Further, the plaintiff is entitled to monetary damages stemming from 'the depreciation in the market value of the property injured' (a 'diminution of value' standard). ${ }^{70} \mathrm{I}$ argue, then, that a nuisance cause of action is just as apt in the land art context, where publication of photographs or films that misrepresent, distort, or otherwise present works like the jetty unfavorably, detracting from its overall appeal, could cause irreparable

${ }^{63}$ See Hendricks v. Stalnaker, 380 S.E.2d 198 (Sup. Ct. Va 1989) (discussing early cases dating from the late 1800 s through the mid-1900s applying nuisance law).

${ }_{64}$ See Jacque v. Steenberg Homes, Inc., 563 N.W.2d 154, 159 (Sup. Ct. Wis. 1997) (awarding punitive damages in the absence of actual harm due to 'the loss of the individual's right to exclude others from his or her property').

${ }^{65}$ Restatement (Second) of Torts $\S 826$ (1979) (noting that 'the gravity of the harm[]' must 'outweigh[] the utility of the actor's conduct' to be considered a nuisance).

${ }_{66}$ See, e.g., Medford v. Levy, 8 S.E. 302 (W. Va. 1888) (cooking odors as nuisance); St. Helen's Smelting Co. v. Tipping, 11 H.L.C. 642, 11 Eng. Rep. 1483 (House of Lords 1865) (noxious vapors constitute a nuisance); Boomer v. Atlantic Cement Co., Inc., 257 N.E.2d 870 (Ct. App. N.Y. 1970) (dirt, smoke, and vibration emanating from nearby plant actionable as nuisance).

67 Hendricks, 380 S.E. $2 d$ at 200.

68 See, Restatement (Second) of Torts $\S 826$ (1979).

69 See, Greenberg, supra note 44.

7010 A.L.R.2d 669 (1950). 
damage to the value of the jetty itself and therefore constitutes a nuisance that must be enjoined.

While almost all nuisance cases up to date have balanced a homeowner's right to the enjoyment of his property against another party's right to carry on some arguably harmful activity, a land art owner's right to the enjoyment of his property is fundamentally different from that of a resident. Specifically, the value of his property lies in its public presentation - it is mostly through the dissemination and mass circulation of images or film that favorable public regard is garnered to a remote work of land art otherwise only accessible via pilgrimage. The owner of a work of land art, unlike a homeowner, does not derive enjoyment from living peaceably on the property, which provided the justifications for categorizing noise, pollution, and noxious gases as nuisances. Rather, land art owners derive enjoyment solely via the good reputation (translating directly to higher market value) his work enjoys. ${ }^{71}$ For the same reasons that a loud plant operation must be enjoined if it interferes with a homeowner's right to quiet enjoyment, so the mass-scale circulation of unfavorable unauthorized photographs must be prohibited to prevent the depreciation in value of the art owner's property.

Using nuisance in lieu of copyright essentially weighs the same balancing interests that copyright law is concerned with. That is, copyright is not an absolute monopoly. The fair use doctrine, which allows the appropriation of a copyrighted work in limited instances, is, like nuisance law, a balancing test that weighs the interest of the copyright holder against the interest of the defendant..$^{72}$ The four-factor fair use test weighs the purpose and character of the infringing use (whether it is transformative - that is, adding 'new aesthetics, new insights and understandings' to the original work $)^{73}$ with the nature of the copyrighted work (fictional works get more copyright protection than nonfictional works),${ }^{74}$ the amount of the work taken, and the effect of the infringing use on the market or value of the copyrighted work. ${ }^{75}$

71 There has been much literature written on the effect an artist's reputation has on the value (translated via market price) of his work. See, e.g., Henry Hansmann and Marina Santilli's article, Authors' and Artists' Moral Rights: A Comparative Legal and Economic Analysis, 26 J. Legal Stud. 95, 104-5 (1997); Gladys Engel Lang and Kurt Lang, Recognition and Renown: The Survival of Artistic Reputation, 94 Am. J. Soc. 79, 105 (1988); Tang, supra note 9, at 234-5.

7217 U.S.C. $§ 107$ (2006).

73 Pierre N. Leval, Toward a Fair Use Standard, 103 Harv. L. Rev. 1105, 111 (1990).

${ }_{74}$ American Geophysical Union v. Texaco Inc., 60 F.3d 913, 925 (2d Cir. 1994).

7517 U.S.C. $§ 107$ (2006). 
A nuisance balancing test applied in the art context would take much of the same considerations into play. Specifically, the 'nuisance' - in other words unauthorized representation in the form of a photo or film - must be harmful in some way, and, as in fair use, severely affect the market or value of the work (the 'diminution of value' standard) without adding any tangible benefits or transformative value. Such a requirement recognizes that there is a broad public interest in art that copyright law itself acknowledges and serves - the public interest in being enriched, in appropriating knowledge, and in building on the works of others in order to create more works. By balancing the rights of the real property owner and the social value of the activity said to constitute a nuisance, nuisance law strangely mimics fair use's balancing test of the rights of the copyright holder against the social value of the new, infringing work.

We can also see this concern with balancing public good and private rights in the unfavorable treatment Kelley and Phillips accorded sitespecific art. Underlying both courts' reluctance to allow the artists' complete control of these works, installed and displayed on public grounds, could be the fact that these works were precisely that - public art, sponsored and owned by the city and created with public funds. If copyright law was already deeply concerned with the appropriate balancing of a rights holder's monopoly power and the public interest in art's progress (specifically, the Constitution's Copyright Clause allows Congress ' $[t]$ o promote the Progress of Science [broadly meaning knowledge] ... by securing for limited Times to Authors ... the exclusive Right to their ... Writings'), ${ }^{76}$ then allowing one artist to prohibit the public from either touching a sculpture or else taking a photograph as a keepsake seems to take the right too far. Land art, in bringing art out of the sacred space of the museum and into life, should likewise welcome the contingencies and human interaction, modification, recreation, or personal memorialization that life thrusts upon it.

At last, it may seem obvious but nonetheless bears pointing out that nuisance, unlike fair use, does not require that the new use be valuable at all. We might analogize nuisance law's requirement that any interference with an owner's property be substantial to the doctrine of de minimis use in copyright law. That is -trivial uses (like reproducing an image to hang on one's refrigerator) ${ }^{77}$ are not considered copyright infringement. Likewise,

76 U.S. Const. art. I, $\S 8$, cl. 8.

77 Ringgold v. Black Entertainment Television, Inc., 126 F.3d 70, 74 (2d. Cir. 1997). 
images taken of Smithson's jetty from a personal trip and posted on one's travel blog, for example, are likely so de minimis as to constitute a nonnuisance. In that instance, an artist cannot argue that such a reproduction has materially interfered with his rights in his work.

\section{CONCLUSION}

Some great works of land art will no doubt become as iconic as the natural wonders that draw visitors from the world over each year. Smithson's man-made jetty thus could easily rival the Grand Canyon in the years to come. But the future of the jetty - including its status as a copyrightable artwork - is hard to predict.

The continued development of these works in the expanded field must similarly expand beyond the modernism-inflected, medium-specific, selfcontained ethos of copyright law. To be like life, to be in the everyday, to expand the realm of possibility, the new sculpture must necessarily appropriate legal remedies once thought of as more fitting for homeowners than artists, for real, grounded property rather than intellectual property. Similarly, courts should remain open to these untraditional remedies as one way of addressing the non-fixed, land/art hybrid of the new expanded medium. These remedies, of course, are imperfect: as with Chapman's wildflowers and Phillips' stoneworks, the artwork owner's interests may be opposed to the artist's interests, and in many best-case scenarios artists must rely on property owners with aligned interests, like the Dia Art Foundation, for a work's conservation and preservation. But then again, life itself, which earthworks take as their base, is imperfect. The desire for absolute control over a work of one's own, like the desire to leave one's mark on the world - etched in larger-scale format, permanent for now, and hopefully for all time - is a natural, albeit megalomaniacal, human urge. Land art's inevitable impermanence lends it mortality's tragedy, along with a strange sense of otherworldly potency and urgency.

I recently journeyed across the American southwest, on a mission to check certain of these works off of the great bucket list of life - the jetty, the 'Lightening Field', Nancy Holt's 'Sun Tunnels' in Utah, and, finally, Michael Heizer's 'Double Negative' in Nevada. On the day we went to 'Double Negative', it had been pouring, and the 'road' leading to the artwork was all but washed out. After twenty minutes of driving through brush, we finally got out of the car and peered over the edge of the work - two man-made canyons carved into opposite sides of a mesa. It was beautiful, despite the fact that time had already started to take its toll on the work - the 'canyons' were only about half as large as they used 
to be, as the sedimentary rock had been crumbling for years. There was not a single other person there. The downpour had subsided into a light mist. Above us, the sky was gray, and all around us, the land was barren, arid, shades of brown and dust red. The work was remarkable. But it was only until we clambered to the edge of the mesa and looked out at the lush green of the valley below that the Wordsworthian sublime, of man at the very top of that summit, began to overtake me. Heizer may have made the canyons, but he didn't make that river running through the valley, which stained all the brown and rust with an impenetrable green, the green of life. At the end of the day, the art had been bested - by life itself. Or perhaps, after all, that was the point. Where did the work end, and the rest of life begin? 